\section{Research on Employee Performance through Transactional Leadership and Organizational Commitment: A Case in FPT University Danang}

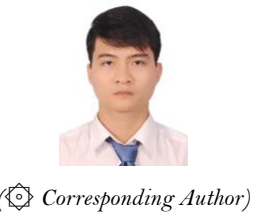

\author{
iD Trinh Le $\operatorname{Tan}^{1} \&$ \\ iD Nguyen Quoc Quan² \\ iD Tran Minh Tung ${ }^{3}$
}

American Journal of Social Sciences and Humanities

Vol. 6, No. 1, 27-38, 2021

e-ISSN: 2520-5382

The quality of training in FPT University Danang (FUDN) is considered as most important criteria in strategic development. In order to advanced quality of training FUDN always focus on human resource quality. In order to increase employee performance, there are many solutions for it, therefore we need to discover factors affecting for specific case. This research have tested relationship between transactional leadership, organizational commitment and employee performance. Authors using previous studies for collecting secondary data and recommendation proposed research model, Through all items of each measurement, authors design questionnaire and survey 55 instructor and staff in FUDN. We use quantitative research for testing hypostheses in proposed research model. Data was analyzed by SPSS 20 through statistic technique. Research have shown that Transactional leadership and Organizational commitment affect to employee performance. FUDN board need to create effective policy as well as changing leadership style to increase commitment from employee and attract high talent instructor.

Keywords: Transactional leadership, Organizational commitment, Employee performance.

DOI: $10.20448 / 801.61 .27 .38$

Citation | Trinh Le Tan; Nguyen Quoc Quan; Tran Minh Tung (2021). Research on Employee Performance through Transactional Leadership and Organizational Commitment: A Case in FPT University Danang. American Journal of Social Sciences and Humanities, 6(1): 27-38.

Copyright: This work is licensed under a Creative Commons Attribution 3.0 License

Funding: This study received no specific financial support.

Competing Interests: The authors declare that they have no competing interests.

History: Received: 28 May 2021/ Revised: 25 June 2021 / Accepted: 19 July 2021/ Published: 23 August 2021

Publisher: Online Science Publishing 


\section{Highlights of this paper}

- Successful factors of implementation electronic customer relationship management (e-CRM) on e-commerce company.

- Factors Affecting Startup Performance of Small and Medium-sized Enterprises in Danang City.

- Issues of implementing electronic supply chain management (E-SCM) in enterprise.

\section{INTRODUCTION}

Human Resources is of paramount importance for FUDN since its role as the executor of FUDN policy implementation and varied operational activities. In order to remain existing, FUDN should be audacious to face many challenges and its implications that is, to adapt to change and win the rivalry. Douglas and Brown (2000) explained that FUDN needs employee who possesses high level of job performance. Human resources have significant role in FUDN because human being is one of the moving spirit of all FUDN's activities (Suyuthi, Hamzah, \& Payangan, 2010).

The success of an organization is highly influenced by its employee individual performance. Rivai and Veithzal (2004) stated that employee performance is reflected as work achievement resulted in accordance with the role of each employee in the FUDN. Employee performance is closely related to performance evaluation; therefore employee performance evaluation needs to be done by the organization. Performance evaluation is defined as a process to measure or evaluate the result of work carried out by individual or group in organization (Rivai \& Veithzal, 2003). To know employee's performance, it is proven by job evaluation assessed by the leader. Performance evaluation is used broadly to manage salary, to give performance feedback, and to identify strength and weakness of employee individually.

Gibson (1994) postulated that organization performance depends on its employee performance, or in other words, employee performance will give contribution to the organization performance. Good performance will show optimum and standardized performance based on the organization standard in order to support organization's goal and vice versa.

Some factors influencing employee performance are leadership style, environment, work life quality, and organizational commitment. One of the pivotal factor determining employee performance and the ability of organization to adapt to environment change according to Bass and Avolio (2006) and Locander, Hamilton, Ladik, and Stuart (2002) is leadership. Leadership illustrates the relationship between leader and follower, more how a leader directs the follower will determine in reaching leader's goal and expectation. Leader develops and directs subordinate's potency and ability to reach or even exceed the organization's goals.

Two types of fast growing leadership style are transactional and transformational leadership introduced by Bass in 1985. Both are based on style, behavior and situation encountered by leader. Transformational leadership style can change and motivate follower by increasing the awareness of task importance and value, getting them to focus first on team or organizational goals rather than their own interests, activating their higher-order needs while transactional leadership style involves exchange process resulting follower's obedience to the leader, however, it does not build enthusiasm and commitment towards task's targets (Yukl, 2010).

Transactional leadership is based on transaction principle or exchange of leader and subordinate. Leader administers certain rewards (such as, bonus) for subordinates who are able to meet leader's expectation; high employee performance (Maulizar, Musnadi, \& Yunus, 2012). According to Yukl (2010) transactional leadership enables to involve values, more those values are relevant to exchange process, and they are honesty, responsibility, and mutuality. 
Transactional leadership style supports one of Maslow's hierarchies, that is, employee's need for appreciation or self-actualization. In this era, appreciation and self-actualization is considered necessary for employee's mental condition as part of self-motivation which can generate them to keep making achievement and giving expected performance.

Another factor that can increase the performance is organizational commitment, which has important role in improving employee's performance. Organizational commitment is exhibited in attitude of acceptance, strong believe on organization values and goal, and strong motivation to stand in membership of organization in order to reach organization's goals (Sawitri, 2011). Organizational commitment is associated to employee's loyalty to the organization; therefore, if an employee has high level of organizational commitment, it will influence the employee performance. Robbins and Judge (2007) contended that commitment is the state of individual taking sides to organization as well as the objectives and his desire to maintain his membership in the organization.

Pounder (2001) argued that organizational commitment can be said as the level of trust and acceptance of employee to the goals of organization and desire to remain in the organization. Having organizational commitment in employee performance improvement enables to affect leadership performance of the FUDN. There is a strong relationship between leader and follower, thus the success of leader in managing the organization cannot be separated from follower's role.

Previous research that support this research reveals that various leaderships roles are needed to influence employee to give their best performance, including transformational and transactional leadership that can have impact on improving employee performance (Bangun \& Wilson, 2012; Locander et al., 2002; Maulizar et al., 2012; Suyuthi et al., 2010; Tondok \& Andarika, 2004). Beside the role of organizational commitment is useful to convince the firm about the attitude and seriousness of the action employee in realizing better performance at the firm, so that the commitment of each employee will affect the firm's performance (Allen \& Meyer, 1990; Meyer, Srinivas, Lal, \& Topolnytsky, 2007; Mowday \& Boulian, 2006; Supriyono, 2004).

The phenomena in this study attempts to explain employees' performance who have not met the target or expectation, which can be noticed from the attendance, thereby specified working hours each employee have not been met. Meanwhile, leader of FUDN had put in a great deal of effort to improve employee's performance through socialization of order and work discipline policy including working hour's criteria, reward and sanction system. That information is delivered in the unit working meeting and through circular letter as well as by putting it in information boards. The leaders of FUDN also supervise regularly the employee's job by checking patients' medical records and its medical treatments.

The purpose of this study is to test and analyze the impact of transactional leadership style on organizational commitment of employee' performance. Looking at the gap phenomenon is expected the result of this study can provide a solution for the leadership or managerial in decision making related to improvement and value of performance by utilizing the role of transactional leadership and employee commitment to FUDN's progress.

\section{LITERATURE REVIEW AND HYPOTHESIS}

\subsection{Performance}

The term of performance is derived from job performance words or actual performance (work achievement or actual achievement reached by individual). The performance of employee is individual thing because each employee has diverse level of ability in accomplishing the task. Hasibuan, Malayu, and SP (2005) described that employee performance is work result which can be achieved by individual in carrying out the tasks assigned based on the skill, experience, seriousness and time. Performance is also the result obtained from the functions or indicators of a job 
or a profession within a certain time (Sawitri, 2011). According to Mangkunegara and Anwar (2005) performance is the result of work in quality and quantity achieved by an employee in performing its duties in accordance with the responsibilities given by the FUDN.

Performance is divided into two types; individual performance and organizational performance. Meanwhile, according to Rivai and Veithzal (2004) performance is the real behavior exhibited by every person as work performance generated by employees in accordance with its role in the FUDN. In contrast to Rivai, Bangun and Wilson (2012) said that performance is the result of a job based on job requirements, the usual requirement is called the standard of work that is the expected level of a particular job to be completed and compared to the goals or targets. In the same vein, Mathis and Jackson (2006) argued that performance is basically what is done or not done by employees. The general employee's performance for most jobs includes the following elements: quantity of results; quality of results; timeliness of results; attendance; and ability to cooperate.

\subsection{Performance Appraisal}

Performance can be assessed or measured by several indicators according to Robbins (2006) as follows: (1) quality, it is measured by employee perceptions of the work quality produced and task perfection of employee's skills and abilities; (2) quantity, it is the amount or number produced which is represented in terms of volume, the number of cycle activity completed; (3) timeliness, it is the activity being done or occurring at a favorable or specified time, viewed from coordination perception and the output as well as to maximize the available time for other activities; (4) effectiveness, it is the optimum degree of organization resources usage in order to increase the result of resource in each unit; (5) independence, it is the state of employee to run job functions; (6) Work commitment, it is the degree which employee has work commitment to institution and responsibility to the office.

\subsection{Transactional Leadership}

Handoko (2004) stated that leadership is the ability of an individual to influence other people to reach the goal and target. While Robbins and Judge (2013) defined leadership as the ability to influence group of people towards the achievement of goals. Leadership is highly required for an organization in determining progress and setbacks, and there is no organization can advance without good leadership (Mas'ud, 2004). Without leadership, organization is only a group of scattered and chaotic people. Leadership will turn anything potential into reality. Thus the existence of leadership in the organization is very important in achieving the goals and advancement of the organization. Mulyadi and Rivai (2009) explained that leadership is a process affecting and determining organization's goal, motivating followers' behavior to achieve the goal, influencing them to fix follower's culture, and a process of directing into positive activities related to job in the organization.

Therefore, it can be inferred that leadership is substantial part in organization management, which adhere to the leader in the form of ability and or a process to influence others or individual/group subordinates, so those individuals or group subordinates want to behave as what the leader wants, and fix subordinate's culture, to motivate subordinate's behavior and to direct them into positive activities related to job to achieve organization's goal.

Regarding to transactional leadership, it is the style of leadership which the leader paying attention to interpersonal transaction between the leader and employee involving exchange relationship. The exchange is based on agreement about target classification, work standard, and job assignment. Transactional leadership is also elaborated by Thomas and Velthhouse (1990) as a leadership style which gaining subordinate's motivation by claiming their own interest. Leadership behavior focuses on the task result and good relationship amongst 
employees in exchange to get the desired reward. Transactional leadership pushes the leader to adjust style and behavior to understand follower's expectation. Whereas according to Bass and Avolio (2006) transactional leadership is a leadership in which a leader encourages employees or subordinates to work by providing resources and rewards in return for motivation, productivity and effective achievement of tasks.

Maulizar et al. (2012) argued that transactional leadership is a leadership model in which a leader tends to provide direction to subordinates, as well as reward and punishment for their performance and focus on behavior to guide their followers toward defined goals by clarifying roles and task demands. Transactional leadership has two dimensions that include: (a) active, the leader supervises and seeks deviations from various rules and standards, and takes corrective action; (b) passive, leaders intervene only when standards have not been met (Brown, 2003; Pounder, 2001).

Keller in Tondok and Andarika (2004) suggested that lower needs, such as physiological needs and sense of security, can only be met through the practice of transactional leadership style. The process of transactional leadership can be demonstrated through a number of dimensions of leadership behavior, they are: contingent reward, active management by exception, and passive management by exception.

Based on the mentioned opinion, it can be concluded that transactional leadership is a leadership that involves or emphasizes rewards to motivate subordinates, meaning that this transactional leadership style has behavioral characteristics motivating subordinates by giving a contingent reward and management by exception.

\subsection{The Impact of Transactional Leadership on Employee Performance}

Regarding to the prior studies, transactional leadership style is able to adjust according to employee's expectation. Physical and material needs of subordinates is managed to be fulfilled by the leader, then he will get reward in the form of high degree of employee performance. Transactional leadership relies on transaction principle or the exchange between leader and employee the leader gives certain rewards (e.g. bonus) to the employee if employee is able to meet leader's expectation; high degree of employee performance.

The indicator of transactional leadership success is contingent reward, the leader promises rewards if employee is able to do what they say, for example leader gives allowance to improve disciplines and career path implementation. Second indicator is management based on exception, which means the leader directly supervise what employee does so if there is a mistake, employee can be commanded to fix. Therefore, the hypothesis developed is mentioned in the following:

H1: There is the Impact of Transactional Leadership on Employee Performance.

\subsection{Organizational Commitment}

Organizational commitment generally can be interpreted as an employee attachment to organization where he works. Commitment is demanded by organization to keep competent human resources well-maintained. In view of Mas'ud (2004), the concept of commitment emerges from a study exploring relationships between employees and people. The motivation to study commitment is based on a belief that committed employees will benefit the FUDN for its potential capability and reduce turn over and improve performance (Mowday \& Boulian, 2006).

Organizational commitment is a personal value, which often refers to loyalty to the FUDN or commitment to the FUDN. Meyer et al. (2007) stated that commitment is a force that binds individuals to an act of linkage to one or more targets. Commitment can be realized by norm, and continuity, reflecting the emotional, perceived obligations, and costs in relationships to achieve the target. Organizational commitment according to Robbins (2006) is a status in which an employee identifies a particular organization and expects to maintain membership 
within the organization. High employee engagement can create high organizational commitments that are beneficial to the organization.

Allen and Meyer (1990) proposed three dimensions of organizational commitment, they are: (1) Affective Commitment; that is emotional attachment, identification and involvement in an organization. In this case, individual choose to stay in an organization because of his own desires. (2) Continuance commitment, that is individual commitment based on consideration of what to sacrifice when leaving the organization, In this case, individual decided to stay in the organization because he considers it as a fulfillment of needs. (3) Normative commitment, it is individual beliefs about responsibility to the organization. Individuals remain in an organization because they feel obliged to be loyal to the organization.

According to Supriyono (2004) one can feel bound and committed to the scope of the organization due to the factors of work, position and existence. There is correlation relationship between organizational commitment and other related work. The correlation is described in terms of overall job satisfaction, performance, turnover intention, with the personality of an employee.

Robbins (2001) viewed organizational commitment as a work attitude because it reflects a person's feelings toward the organization where he works. Commitment is an individual orientation towards an organization including loyalty, identification, and engagement. Basically, the term organizational commitment has an emphasis on the process experienced by employees in identifying themselves with the values, rules, and goals of the organization. Organizational commitment implies something more than a passive loyalty to the organization. In other words, organizational commitment infers an active association with the organization.

\subsection{The Impact of Organizational Commitment on Employee Performance}

Organizational commitment, in this case, is the commitment of employees having the position and role as important as the role of leader, which the commitment of employees will be realized through 3 inseparable dimensions; (1) affective commitment, such as emotional attachment and employee involvement in the organization, (2) continuance commitment, which individual commitment considers the sacrifices to be given to the organization and (3)normative commitment, which is indicated by awareness of obligations and loyalty to the organization. Allen and Meyer (1990) hence, a strong organizational commitment of employees will be able to contribute to the improvement of the employee performance and the improvement of FUDN performance on a regular basis. Thus, the hypothesis formulated is as follows:

H2: There is the Impact of Organizational Commitment on Employee Performance.

\section{METHODOLOGY}

Population in this paper are all instructor, staff in FPT University Danang a number of 120 respondent. Because the number of population in known then the sample size is calculated with Slovin Formula so that obtained the sample size of 55 Respondent. The Used Sample with promotional random sampling technique

Variable in this paper was measured using Likert scale 1-5 points. Some variables studied that uses indicators evolved from theory review are: Measurement of Transactional Leadership Variable adopting (Bass \& Avolio, 2006), consists of: Contingent reward, active management-by-exception, and passive management-by exception; Measurement of Organizational Commitment adopting (Robbins, 2009) that is affective commitment, continuance commitment, and normative commitment. Measurement of Employee Performance is also evolved from Robbins (2009), including Quality, Quantity, Timeliness, Effectiveness and Independence (Robbins, 2009).

From linkage of afore theory concepts, research model can be drawn in Figure 1. 


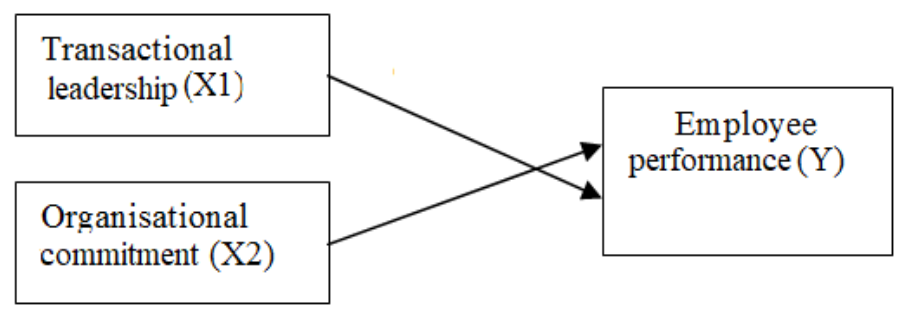

Figure-1. Proposed Research model.

\section{RESULTS AND DISCUSSIONS}

Based on testing of research instrument with SPSS program, it is obtained $r$ count of each item $>r$ table specified (0.361). This shows that all items of the research instrument on all variables are Valid.

Based on Table 1. it is known that obtained $r$ count of the eight items instrument of transactional leadership > $r$ table specified (0361). It's shows that the eight instruments of Transactional leadership are valid.

Table-1. Validity test of transactional leadership variable.

\begin{tabular}{cccc}
\hline No & r count pearson correlation & r-table & Mean \\
\hline 1 & 0.390 & 0.361 & Valid \\
2 & 0.648 & 0.361 & Valid \\
3 & 0.733 & 0.361 & Valid \\
4 & 0.756 & 0.361 & Valid \\
5 & 0.481 & 0.361 & Valid \\
6 & 0.660 & 0.361 & Valid \\
7 & 0.365 & 0.361 & Valid \\
8 & 0.672 & 0.361 & Valid \\
\hline
\end{tabular}

Table-2. Validity test of organizational commitment variable.

\begin{tabular}{cccc}
\hline No & r count pearson correlation & r-table & Mean \\
\hline 1 & 0.459 & 0.361 & Valid \\
2 & 0.630 & 0.361 & Valid \\
3 & 0.484 & 0.361 & Valid \\
4 & 0.538 & 0.361 & Valid \\
5 & 0.743 & 0.361 & Valid \\
6 & 0.620 & 0.361 & Valid \\
7 & 0.583 & 0.361 & Valid \\
8 & 0.648 & 0.361 & Valid \\
9 & 0.758 & 0.361 & Valid \\
10 & 0.626 & 0.361 & Valid \\
\hline
\end{tabular}

Table-3. Validity test of employee performance variable.

\begin{tabular}{cccc}
\hline No & r count pearson correlation & r-table & Mean \\
\hline 1 & 0.707 & 0.361 & Valid \\
\hline 2 & 0.670 & 0.361 & Valid \\
3 & 0.729 & 0.361 & Valid \\
\hline 4 & 0.429 & 0.361 & Valid \\
5 & 0.517 & 0.361 & Valid \\
6 & 0.656 & 0.361 & Valid \\
7 & 0.706 & 0.361 & Valid \\
\hline 8 & 0.520 & 0.361 & Valid \\
9 & 0.676 & 0.361 & Valid \\
10 & 0.430 & 0.361 & Valid \\
11 & 0.447 & 0.361 & Valid \\
\hline 12 & 0.615 & 0.361 & Valid \\
13 & 0.493 & 0.361 & Valid \\
\hline 14 & 0.408 & 0.361 & Valid \\
\hline 15 & 0.420 & 0.361 & Valid \\
\hline
\end{tabular}


Based on Table 2. it is known that obtained r count of the ten items instrument of Organizational Commitment $>r$ table specified (0361). It's shows that the ten instruments of Organizational Commitment are valid.

Based on Table 3. it is known that obtained $r$ count of the fifteen items instrument of Employee Performance $>\mathrm{r}$ table specified (0.361). It's shows that fifteen instruments of Employee Performance are valid.

Similar to the reliability test of variables, it is obtained Cronbach Alpha count $>$ Cronbach Alpha set (0.70). Based on Table 4, this indicates that all items of research variable instrument are reliable.

\section{RESULT OF DESCRIPTIVE ANALYSIS}

The result of analysis description of respondent's answer related to Transactional Leadership can be seen in Table 4 below

Table-4. Descriptive analysis of transactional leadership.

\begin{tabular}{lcccc}
\multicolumn{5}{c}{ Table-4. Descriptive analysis of transactional leadership. } \\
\hline Indicator & $\sum$ score & Ideal score & Percentage K & Mean \\
\hline Contingent rewards & 421 & 550 & $76.54 \%$ & Good \\
Active management & 825 & 595 & $72.12 \%$ & Good \\
Passive management & 825 & 615 & $74.54 \%$ & Good \\
Average & 2071 & 1760 & $74.40 \%$ & Good \\
\hline
\end{tabular}

From Table 4, it is found that transactional leadership variable on average is $74.40 \%$ is included in good category. This suggests that transactional leadership requires elements of contingent rewards, passive management and active management.

The result of analysis description of respondent's answer related to organizational commitment can be seen in Table 5. Based on Table 5, it can be explained that the variable of organizational commitment on average of $76.01 \%$, is included in good category. This suggests that transactional leadership requires affective commitment, continuance commitment and normative commitment.

Table-5. Descriptive analysis of organizational commitment.

\begin{tabular}{lcccc}
\hline Indicator & $\sum$ score & Ideal score & Percentage K & Mean \\
\hline Affective commitment & 825 & 637 & $77.22 \%$ & Good \\
Continuance commitment & 1100 & 837 & $76.09 \%$ & Good \\
Normative commitment & 825 & 619 & $75.04 \%$ & Good \\
Average & 2750 & 2093 & $76.01 \%$ & Good \\
\hline
\end{tabular}

The result of analysis description of respondent's answer related to the commitment of the organization can be seen in Table 6.

Table-6. Descriptive analysis of employee performance.

\begin{tabular}{lcccc}
\hline Indicator & $\sum$ score & Ideal score & Percentage K & Mean \\
\hline Quality & 627 & 825 & $76.00 \%$ & Good \\
Quantity & 610 & 825 & $73.93 \%$ & Good \\
Timeliness & 823 & 1100 & $74.81 \%$ & Good \\
Effectiveness & 603 & 825 & $73.09 \%$ & Good \\
Independence & 408 & 550 & $74.18 \%$ & Good \\
Average & 3051 & 4125 & $73.96 \%$ & Good \\
\hline
\end{tabular}

Based on Table 6, it is explained that the average employee performance variable of $73.96 \%$ is included in good category. This shows that employee performance requires element of quality, quantity timeliness, effectiveness and independence. 


\subsection{Classic Assumption Test}

Result of Normality Test can be seen in Kolomogor of Smirnov test where obtained value KolmogorovSmirnov $\mathrm{Z}$ is 0.930 with Asymp value. Sig (2-tailed) is $0.353>0.05$ then the research data is normally distributed. Normality test results can be seen in Table 7 .

Table-7. Result of classic assumption test.

\begin{tabular}{lc}
\hline $\mathbf{N}$ & Unstandardized residual \\
\hline Normal & 55 \\
Parametersa & 0.0000000 \\
Most extreme & 5.01023280 \\
Differences & 0.125 \\
Kolmogorov-Smirnov & 0.078 \\
Z & -0.125 \\
Asymp. sig. (2-tailed) & 0.930 \\
$\mathrm{~N}$ & 0.353 \\
\hline
\end{tabular}

Another classical assumption test is multicollinearity testing which is seen in each independent variable has a tolerance value $>0.1$ and VIF $<10$ so it can be concluded that therenis no multicollinearity among independent variables in this regression model as in Table 8:

Table-8. Result of multicollinearity test.

\begin{tabular}{cccccccc}
\hline & Model & Std. error & Beta & T & Sig. & Tolerance & VIF \\
\hline $\mathbf{1}$ & (Constant) & 6.272 & 0.674 & & 0.504 & & \\
& X1 & 0.194 & 0.389 & 3.725 & 0.000 & 0.755 & 1.325 \\
& X2 & 0.173 & 0.483 & 4.615 & 0.000 & 0.755 & 1.325 \\
\hline
\end{tabular}

Similarly, heterokedasitas test seen in the Glejser test results obtained that the significance of the resulting count $>0.05$ so it is concluded that there is no heteroscedasticity. Heterokedasity test results can be seen in Table 9.

Table-9. Result of Heterokedasity test.

\begin{tabular}{ccccccc}
\hline & & \multicolumn{2}{c}{ Unstandardized coefficients } & \multicolumn{2}{c}{ Standardized coefficients } \\
\hline & Model & B & Std. error & Beta & T & Sig. \\
1 & (Constant) & 8.837 & 4.114 & & 2.148 & 0.036 \\
& X1 & -0.143 & 0.127 & -0.176 & -1.125 & 0.266 \\
& X2 & -0.023 & 0.114 & -0.032 & -0.205 & 0.838 \\
\hline
\end{tabular}

\subsection{Result of Hypothesis Testing}

Based on Multiple Regression Analysis Test with SPSS program, it can be obtained the following results:

Table-10. Multiple regression analysis result.

\begin{tabular}{ccccccc}
\hline & & \multicolumn{3}{c}{ Unstandardized coefficients } & \multicolumn{3}{c}{ Standardized coefficients } \\
\cline { 2 - 7 } 1 & Model & B & Std. error & Beta & T & Sig. \\
& (Constant) & 4.225 & 6.272 & & 0.674 & 0.504 \\
& $\mathrm{X}_{1}$ & 0.722 & 0.194 & 0.389 & 3.725 & 0.000 \\
\hline & $\mathrm{X} 2$ & 0.799 & 0.173 & 0.483 & 4.615 & 0.000 \\
\hline
\end{tabular}

Based on the results of multiple regression tests in Table 10, it can be seen that the transactional leadership variable has $t$ value of 3.725 with a significance of $0.000<0.05$ Thus, $\mathrm{H}_{1}$, which states that there is an impact of transactional leadership on employee performance, is accepted. Acceptance from hypothesis one (H1) can be explained through 3 indicators that is contingent rewards, active management and passive management within 
FUDN. Some of contingent reward are giving periodic briefing to his employees, and giving bonuses to his employees for the performance that has been completed. While passive management, the leadership gives sanctions (warning) to employees if their work is not in accordance with FUDN procedures, leader will also provide opportunities for employees to fix the mistakes of their work. Likewise with active management, the leader supervises directly or periodically every activity in the FUDN. The results of this study are in line with the study conducted (Bass \& Avolio, 2006; Yukl, 2010) which stated that there is an impact of transactional leadership on employee performance.

Similarly in organizational commitment variable, it is obtained t count of 4.615 with a significance of $0.000<$ 0.05. Thus, H2 stating that there is an impact of organizational commitment on employee performance is accepted. Acceptance of hypothesis two (H2) can be explained that the organizational commitment or employees will be able to improve employee performance which is supported by the affective commitment, continuance commitment and normative commitment.

Affective commitment, employees will feel happy, proud to work and become part of the FUDN. Employees will also deliver the performance results expected by the FUDN. While continuance commitment, employees will feel more motivated in working if their work is rewarded by the FUDN, employees will also feel comfortable in work because social security provided by the FUDN has been in accordance with the employee expectation. It also happens to the normative commitment, employees will still work in the FUDN even though there are job offers in other companies, and employees will also keep the cooperation with employees or with the leadership without being asked.

The results of this paper are in accordance with the research described by Locander et al. (2002); Tondok and Andarika (2004); Suyuthi et al. (2010); Bangun and Wilson (2012) and Maulizar et al. (2012) in which transactional leadership have impact on employee performance. So that Organizational commitment research are accordance with the last research which proves that organizational commitment affects employee performance (Allen \& Meyer, 1990; Meyer et al., 2007; Mowday \& Boulian, 2006; Supriyono, 2004).

\section{CONCLUSIONS}

Based on the aforementioned result and discussion, it can be concluded that the impact of transactional leadership on employee performance is proven.

It means that the better the FUDN leader implements transactional leadership, the better improvement of employee performance. It is declared to be true that there is the impact of organizational commitment on employee performance, which means that the better employee commitment in their job, the better improvement of employee performance. Overall, transactional leadership and organizational indicators have been done well, but active management indicator needs to be improved by letting the leader being active in supervising and directly involved in incidental activities.

Thereby the FUDN leader can understand obstacles encountered by the employee. It is acknowledged that this case study still has limitation and tenacity. It is expected that further researchers are possible to develop research model by adding or combining other suggested variables from prior researches, such as motivation, environment, culture and so forth. Thus, factors influencing employee performance will more visible. To generalize this result of study, in-depth further researches with non-service firms as the object need to be done. 


\section{REFERENCES}

Allen, N. J., \& Meyer, J. P. (1990). The measurement and antecedents of affective, continuance and normative commitment to the organization. Journal of Occupational Psychology, 63(1), 1-18. Available at: https://doi.org/10.1111/j.20448325.1990.tbo0506.x.

Bangun, \& Wilson. (2012). Leadership and performance beyond expectations. Bandung: Erlangga.

Bass, B. M., \& Avolio. (2006). Leadership and performance beyond expectations. New York: The Free Press.

Brown, B. B. (2003). Employees' organizational commitment and their perceptions of supervisors' relations-oriented and task-oriented leadership behaviors. Doctoral Dissertation, Virginia Tech.

Douglas, \& Brown, H. (2000). Principles of language learning and teaching. San Fransisco: Fransisco State University.

Gibson. (1994). Ortganization behaviour, structure an proses, Organisasi, perilaku, struktur dan proses (terjemahan Nunuk Ardiani). Jakarta: Bina Aksara.

Handoko, T., H. (2004). Personnel and human resource management. Yogyakarta: BPFE.

Hasibuan, Malayu, \& SP. (2005). Human resource management. Jakarta: Earth Literacy.

Locander, W. B., Hamilton, F., Ladik, D., \& Stuart, J. (2002). Developing a leadership-rich culture: The missing link to creating a market-focused organization. Journal of Market-Focused Management, 5(2), 149-163.

Mangkunegara, \& Anwar, P. (2005). Corporate human resource management (3rd ed.). Bandung: PT: Remaja Rosdakarya.

Mas'ud, F. (2004). Organizational diagnostic survey concepts \& applications. Semarang: Diponegoro University Publishing Agency.

Mathis, \& Jackson. (2006). Human resources management: Human resource management, Translated Dian Angelia (10th ed.). Publisher Salemba Empat: Jakarta.

Maulizar, Musnadi, \& Yunus. (2012). The influence of transactional and transformational leadership on the employee performance of Bank Syariah Mandiri Branch Banda. Journal of Management Science, 1(1), 1-13.

Meyer, J. P., Srinivas, E. S., Lal, J. B., \& Topolnytsky, L. (2007). Employee commitment and support for an organizational change: Test of the three-component model in two cultures. Journal of Occupational and Organizational Psychology, 8O(2), 185-211.

Mowday, R. T., \& Boulian, P. V. (2006). Organizational commitment, job satisfaction, and turnover among psychiatric technicians. Journal of Applied Phsychology, 59(5), 603- 609.

Mulyadi, \& Rivai. (2009). Human resource management (Ninth). Jakarta: Rajawali Press.

Pounder, J. S. (2001). New leadership and university organizational effectiveness: Exploring the relationship. Leadership $\mathcal{E}^{\circ}$ Organization Development Journal, 6(22), 281-290.

Rivai, \& Veithzal. (2003). Leadership and organizational behavior. Jakarta: PT: Raja Grafindo Persada.

Rivai, \& Veithzal. (2004). Leadership and organizational behavior. Jakarta: Raja Grafindo Persada.

Robbins. (2006). Organizational behavior, translation Drs. Benyamin Molan (10th ed.). Jakarta: PT: Gramedia Group Index.

Robbins, S. P., \& Judge, T. (2013). Organizational behavior (15th ed.): Pearson.

Robbins, S. P. (2009). Organizational behaviour: Pearson Prentice Hall.

Robbins, S., \& Judge. (2007). Organizational behavior. Salemba Empat: Jakarta.

Robbins, S. P. (2001). Organizational behavior. Jakarta: Prehalindo.

Sawitri, S. (2011). The influence of corporate governance on company performance (Studies on Companies Registered in LQ45 Years 20052009. Semarang: Diponegoro University.

Supriyono, R. (2004). The influence of the intervening variable budget adequacy and organizational commitment on the relationship between budgetary participation and manager performance in Indonesia. Journal of Indonesian Economy and Business, $19(3), 282-298$. 
Suyuthi, N. F. S., Hamzah, H. D., \& Payangan. (2010). The influence of transformational and transactional leadership styles on performance through employee job satisfaction at Pt. Telkom Division VII Makassar. Unhas Makassar.

Thomas, W. K., \& Velthhouse, B. A. (1990). Cognitive element of empowerment: An enterpretative model of Intrinsic task motivation. Academmy of Management Review, 15(4), 666-681.

Tondok, S. M., \& Andarika, R. (2004). The relationship between transformational and transactional leadership styles with employee job satisfaction. Psyche, 1(1), 35-48.

Yukl, G. (2010). Leadership in organizations. (T. Supryanto, Ed.) (5th ed.). Jakarta: PT: Index.

Online Science Publishing is not responsible or answerable for any loss, damage or liability, etc. caused in relation to/arising out of the use of the content. Any queries should be directed to the corresponding author of the article. 